\title{
A Taxonomy of Theories about ICTs and Society
}

\author{
Wolfgang Hofkirchner
}

Institute for Design and Technology Assessment, Vienna University of Technology, wolfgang.hofkirchner@tuwien.ac.at

\begin{abstract}
How is the relationship between ICTs and society to be conceived? And how is this relationship to be evaluated? These two questions form the basis for building an ideal-typical categorisation of different theoretical approaches. The scheme offers an opportunity to be conscious of the advantages and disadvantages of certain ways of theorising.
\end{abstract}

Keywords: Ways of thinking, technodeterminism, social constructivism, mutual-shaping approach, eutopianism, dystopianism, design theories

For little more than the last ten years there has been a remarkable shift in the fields of ScienceTechnology-Society, Communication Studies, Computer Science and adjacent fields towards more recognition of the role ICTs play for the advent of the Information Society (or whatever term may be used to depict the society that is said to deeply depend on ICT use). Fields of overlapping and converging concerns on different levels of abstraction like Internet Research, New Media Studies, Social Informatics, and so on, have emerged and has been given an "infrastructure" by the creation of a variety of research centers and academic positions within established disciplines. A network of researchers engaged with ICTs and society was established only recently. It is devoted to reflecting on the foundations of, and to giving shape to, the new field. It is clear that this field has not had much time to develop. Thus the body of theories is yet to be elaborated as is the toolbox of methodologies. Kim and Weaver (2002) published a comprehensive study on Internet Research. They found that there are a large number of empirical studies about the Internet in terms of content and audience research as well as traditional approaches derived from mass communications. Theoretical considerations, however, do not take center stage. For example, volume 21, issue number 2 of The Information Society (2005) addressed the as-yet-to-be-sharpened profile of this new field.

There is, however, a long history literature on information society theory that has provided a diversity of different approaches. The aim of this paper is to develop a taxonomy that helps identify fallacies and shortcomings, on the one hand, and essential viewpoints that must be taken into account, on the other, and thus to contribute theoretical insights in the field of ICTs and Society that orient and substantiate research. In particular, the paper discusses how determinants and values are viewed.

\section{Ways of thinking}

The basic proposal begins with classification in order to discover or construct "archetypes" of information society theories makes use of the concept of "ways of thinking" developed elsewhere (Hofkirchner, 1999). 
What is a way of thinking? A way of thinking is the way how identity and difference are thought to relate to each other. Relating identity and difference may be presumed to be the most basic function of thinking. It appears in praxiological, ontological and epistemological contexts. That is, practical problems that come to thought, entities that are investigated, phenomena that have to be perceived, may be identical in certain respects but may differ from each other in other respects.

That what differs is more complex than that from which it differs, but, by the same token, creates an integrated whole. The question arises as to how the simple does relate to the complex, that is, how less complex problems or objects or phenomena do relate to more complex ones.

The first way of thinking, in terms of ideal types, establishes identity by eliminating the difference for the benefit of the less complex side of the difference and at the cost of the more complex side. "Higher complexity" is reduced to "lower complexity". Known as reductionism, it remains the mainstream of the natural sciences.

The counterpart of the reductive way of thinking is what might be called the "projective". Projective thinking also establishes identity by eliminating the difference, albeit for the benefit of the more complex side of the difference and at the cost of the less complex side. It takes the "higher" level of complexity as its point of departure and extrapolates or projects from there to the "lower" level of complexity. It overestimates the role of the whole and belittles the role of the parts. This is one trait of the humanities. Both the reductive and the projective way of thinking yield unity without diversity.

There is a third way. It eliminates identity by establishing the difference for the sake of each manifestation of complexity in its own right. It abandons all relationships between all of them by treating them as disjunctive. It dissociates one from the other. It dichotomises and yields dualism (or pluralism) in the sense of diversity without unity. Let's call it disjunctivism. The often bemoaned chasm between the so-called two cultures of hard science and soft science (humanities) is the most striking example for this way of thinking. In fact, this is a description of the state of the scientific adventure as a multiplicity of monodisciplinary approaches that are alien and deaf towards each other.

And, finally, there is a fourth way of thinking, integrativism, that is opposed to reductionism, projectivism and disjunctivism. This is a way of thinking that establishes identity as well as difference favouring neither of the manifestations of complexity. It establishes identity in line with the difference. It integrates both sides of the difference (yielding unity) and it differentiates identity (yielding diversity). It is a way of thinking that is based upon integration and differentiation. It is opposed to both dissociation and unification and yields unity and diversity in one. It integrates "lower" and "higher complexity" by establishing a dialectical relationship between them.

\section{The question of the determinant: is there an independent variable and, if yes, which is it?}

Theories about information society are about the relation between ICTs and society. In this respect, they can be classified according to the underlying way of thinking. This works, if it is assumed, (1) that ICTs are part of society and that a part is less complex than the whole to which it belongs; and (2), that non-technological societal factors are more complex than technological ones because the former belong to a subsystem of higher order than that subsystem of which technology is part (Hofkirchner \& Fuchs, 2003). In other words, information society theories can be differentiated according to which factor is considered as the independent variable, that is, ICTs or some non-technological societal factor.

Theories that are based upon the premise that ICTs are the independent variable can be categorised as reductionist, since the whole of society is reduced to some part. These theories are known as technological determinism.

In turn, theories that make a societal factor the independent variable can be classified as projectivistic. These are known as social constructivism, since technology is treated as a social 
construct. These theories assign ICTs as the dependent variable. The independent variables can belong to nature as so-called environment, to economy, polity or culture or their parts.

It is worth noting that reductionism as well as projectivism as categories are ideal types and signify strict or complete determinism. They can be characterised by the following propositions: if ICTs, then (informatised) environment, economy, polity or culture, in the first case; if (informational) environment, economy, polity or culture, then ICTs, in the second case.

In opposition to these two cases, theories that do not acknowledge any determination, that is, any dependence on ICTs or any dependence on some societal factor, would have to be called disjunctivist. They are rare but might be fuelled by postmodern philosophy.

Finally, theories that do consider the relationship of ICTs and society neither as strictly determined by one or the other nor as completely independent from each other, fulfill the criterion of the fourth way of thinking, integrativism. The part determines the whole but is, in turn, determined by the whole. The less complex makes up the more complex but is, in turn, influenced by the more complex. In no direction is there strict determinism. ICTs have an impact on society and its parts but the impact is not predestined. ICTs are produced by society and bear the stamp of it but are not deemed to be instrumental in conveying dominant social interests and motives exclusively. Following the so-called social-shaping approach, which in case of clear-cut determinism would go as projectivist, this integration of technological and societal factors can be termed a "mutual-shaping" approach in that technology shapes society and society shapes technology (Herdin, Hofkirchner, \& Maier-Rabler, 2006).

\section{The question of values: what are the opportunities and risks?}

Information society theories not only aim at explanations of the relationship between ICTs and society, also evaluate this relationship.

If they look upon it favourably and highlight the opportunities, they are called eutopian. If they look upon it unfavourably and underline the risks, they are called dystopian. Here too the distinction is an ideal-typical one. This distinction holds not only for reductionism (technological dterminism) but for projectivism (social constructivism) as well.

Accordingly, a we can create a two-dimensional table to yield a taxonomy of two dimensions. One dimension distinguishes determinants based upon four ways of thinking and the other dimension describes values inherent in information society. Determinants build the lines of the table and values the columns (see Table 1).

Utopianism as well as dystopianism, as far as they build upon determinism, are not consequential for acting. It is the inevitable to which they ascribe either a positive or a negative value. In the case of utopianism it is progress that is inevitable and then either technological progress produces social progress or social progress produces technological progress. In the case of dystopianism it is regress that is inevitable and then, again, either technological regress produces social regress or the other way round.

The indeterminism variant of information society theory, be it utopian or dystopian, would not be consequential for practice either, since ICTs cannot influence society and society cannot influence ICTs. As such, the development of a technology that might be evaluated in a positive or a negative way might or might not be paralleled by a respective development of society.

The only category of theories that are able to inform and guide action is to be located beyond the distinction of utopia and dystopia. It is the only pro-active one. Since, according to it, development of ICTs and society is not a fate, both have to be designed in order to turn development into progress. Thus the table needs an additional column next to the utopianism/dystopianism distinction.

\section{Illustration}

Given the caveat that Table 1 demonstrates a scheme of possible clear-cut positions in information society theory and does not claim to actually reproduce an unambiguous mapping of 
existing positions, the attempt is made to name clusters that fall near certain categories (see Table 2).

\begin{tabular}{|c|c|c|c|c|}
\hline \multicolumn{2}{|c|}{ Determinants } & \multicolumn{3}{|l|}{ Values } \\
\hline & & Eutopianism & Dystopianism & Proactive approach \\
\hline \multicolumn{2}{|c|}{$\begin{array}{l}\text { Technology } \\
\text { (technodeterminism: } \\
\text { reduction) }\end{array}$} & $\begin{array}{l}\text { Technological } \\
\text { progress = social } \\
\text { progress }\end{array}$ & $\begin{array}{l}\text { Technological } \\
\text { regerss = social } \\
\text { regress }\end{array}$ & - \\
\hline \multirow{4}{*}{$\begin{array}{l}\text { Societal } \\
\text { (social } \\
\text { construc- } \\
\text { tivism: } \\
\text { projection) }\end{array}$} & $\begin{array}{l}\text { Nature as } \\
\text { environment }\end{array}$ & \multirow[t]{4}{*}{$\begin{array}{l}\text { Societal progress }= \\
\text { technological } \\
\text { progress }\end{array}$} & \multirow[t]{4}{*}{$\begin{array}{l}\text { Societal regress }= \\
\text { technological } \\
\text { regress }\end{array}$} & \\
\hline & Economy & & & \\
\hline & Polity & & & \\
\hline & Culture & & & \\
\hline \multicolumn{2}{|c|}{$\begin{array}{l}\text { None (postmodernism: } \\
\text { disjunction) }\end{array}$} & \multicolumn{2}{|c|}{$\begin{array}{l}\text { Technological development } \neq \text { social } \\
\text { development }\end{array}$} & \\
\hline \multicolumn{2}{|c|}{$\begin{array}{l}\text { Both } \\
\text { (mutual-shaping approach: } \\
\text { integration) }\end{array}$} & \multicolumn{2}{|l|}{-} & $\begin{array}{l}\text { Both technological } \\
\text { design and societal } \\
\text { design }\end{array}$ \\
\hline
\end{tabular}

Table 1: Classification of Theories Relating Technological and Societal Development according to Determinants and Values

Information society theory in the literal sense might be found near the cell in line one, column one. These "digitisation theories" praise the advantages for environment, economy, polity, culture that are "pushed" by ICTs like Negroponte (1995) did.

Theories of a society developing ICTs for the sake of managing natural resources (as to the environment), theories of knowledge society for the sake of providing access to the knowledge of the world for all, in particular, to better capacitate the people to earn their living (regarding economy), theories of a participatory society for the sake of empowerment of the people (at the political level) and, finally, theories of fun and leisure societies or the like (concerning culture) have can be placed in the cell in row two-column one. They may be identified as social constructivist and can therefore be called, after Rheingold (1993), "community-building theories". The common theme these theories share is the existence of certain social needs and interests that "pull" technology.

Theories of virtual society (which, actually, is the title of a book by Bühl [1997]) are, so to speak, attracted by the cell in row line-column two. This is the cell of dystopian techno-determinism. Pessimistic technological deterministic theories bemoan the loss of social reality through the emrgence of the virtual world, the virtual space, cyberspace, and the simulacrum: man is becoming alienated from his fellow humans and emigrates to isolation; truth is no longer something to be intersubjectively consolidated but a plurality of subjective worlds. These "virtualisation theories" have been brought forward by French philosophers like Baudrillard (1995) and Virilio (2000). 


\begin{tabular}{|c|c|c|c|c|}
\hline \multicolumn{2}{|c|}{ Determinants } & \multicolumn{3}{|l|}{ Values } \\
\hline & & Eutopianism & Dystopianism & Proactive approach \\
\hline \multicolumn{2}{|c|}{$\begin{array}{l}\text { Technology } \\
\text { (technodeterminism: } \\
\text { reduction) }\end{array}$} & $\begin{array}{l}\text { "Information } \\
\text { society" }\end{array}$ & "Virtual society" & - \\
\hline \multirow{4}{*}{$\begin{array}{l}\text { Societal } \\
\text { (social } \\
\text { construc- } \\
\text { tivism: } \\
\text { projection) }\end{array}$} & $\begin{array}{l}\text { Nature as } \\
\text { environment }\end{array}$ & $\begin{array}{l}\text { "Managing-earth } \\
\text { society" }\end{array}$ & $\begin{array}{l}\text { "Plundering-the- } \\
\text { planet society" }\end{array}$ & \\
\hline & Economy & $\begin{array}{l}\text { "Knowledge-for-all } \\
\text { society" }\end{array}$ & $\begin{array}{l}\text { "Knowledge- } \\
\text { monopolies society" }\end{array}$ & \\
\hline & Polity & $\begin{array}{l}\text { "Participatory } \\
\text { society" }\end{array}$ & $\begin{array}{l}\text { "Surveillance } \\
\text { society" }\end{array}$ & \\
\hline & Culture & $\begin{array}{l}\text { "Fun-", "Leisure } \\
\text { society" }\end{array}$ & $\begin{array}{l}\text { "Disinfotainment } \\
\text { society" }\end{array}$ & \\
\hline \multicolumn{2}{|c|}{$\begin{array}{l}\text { None (postmodernism: } \\
\text { disjunction) }\end{array}$} & \multicolumn{2}{|l|}{ "Baroque society" } & \\
\hline \multicolumn{2}{|c|}{$\begin{array}{l}\text { Both } \\
\text { (mutual-shaping approach: } \\
\text { integration) }\end{array}$} & \multicolumn{2}{|l|}{ - } & $\begin{array}{l}\text { Global sustainable } \\
\text { information society }\end{array}$ \\
\hline
\end{tabular}

Table 2: Classification of Sample Theories according to Determinants and Values

Theories according to which ICTs are instrumentalised for more effectively plundering of the planet with regard to natural resources, for establishing knowledge monopolies in the economic sphere, for total surveillance by a panspectron which, in the political sphere, extends the Foucauldian panopticon to the whole bandwidth of electro-magnetic waves or, as regards the cultural sphere, for disinfotainment as Rheingold (2002) claims to have coined the term in the beginning of the 1990s - all these "Orwellian theories" are affiliated with dystopian social constructivism (see, for example, Eurich [1991] who provides a bellicose account of the history of communication technology from the outset) and are close to the cell in row two-column two.

The third row, columns one and two, provides a home for theories of unequal development of technology and society in the way Kaldor's (1982) Baroque hypothesis or Becker's (2002) position seem to indicate. These theories might be called "decoupling theories".

True "design theories", in the broader sense of shaping ICTs for a global and sustainable information society, of Technikgestaltung, as the German term expresses very concisely, and social systems design (see Banathy [2000]) are candidates for the cell in row four, column 4 , represented by, among others, Castells (2001). After Castells, the "network society", as he calls contemporaneous society, is the result of an interplay of different developments. On the one hand, networks are social organisational forms which in former times have been less efficient than hierarchies, as can be seen in the military or in business. By means of the production of technology that offers the potential to increase the efficiency of networks to an extent going beyond the efficiency of hierarchies, these possibilities tend to be realised.

\section{Conclusion}

A scheme that describes the theoretical stances of how ICTs and Society relate by the supposed independent variable and by the value ascribed to it allows for a taxonomy that is useful for bridging the gap between the rapid development of recent empirical research in the domain and the 
thread of information society theories dating back to the beginnings of the so-called information revolution. It is design theories in the broader sense that seem best suited to guide empirical research and practical policy.

\section{References}

Banathy, B. A. (1996). Designing social systems in a changing world. New York: Plenum.

Baudrillard, J. (1995). Simulacra and simulation. Ann Arbor, MI: The University of Michigan Press.

Becker, J. (2002). Information und Gesellschaft. Wien: Springer.

Bühl, A. (1997). Die virtuelle Gesellschaft. Wiesbaden: Westdeutscher Verlag.

Herdin, T., Hofkirchner, W., \& Maier-Rabler, U. (2006). Culture and technology: A mutual shaping approach. In S. Hongladarom \& C. Ess. (Eds.), Information technology ethics (pp. 57-64). Hershey: Idea Group.

Hofkirchner, W. (1999). Ways of thinking and the unification of science. In J.K. Allen, M.L.W. Hall, , \& J. Wilby (Eds.), Proceedings of the 43rd Annual Conference of ISSS (pp. 1-12). York: International Society for the Systems Sciences Business Office (CD-ROM).

Hofkirchner, W., \& Fuchs, C. (2003). The architecture of the information society. In J. Wilby \& J.K. Allen (Eds.), Proceedings of the 47th Annual Conference, ISSS (pp. 1-10). York: International Society for the Systems Sciences Business Office (CD-ROM).

Hofkirchner, W. (2007). Theorien der Informationsgesellschaft. Sitzungsberichte der Leibniz-Sozietät, 93, 101-117.

Kaldor, M. (1982). The baroque arsenal. New York: Hill and Wang.

Kim, S.T., \& Weaver, D. (2002). Communication research about the Internet. New Media and Society, 4, 518-539.

Negroponte, N. (1995). Being digital. New York: Knopf.

Rheingold, H. (2002). Smart mobs. Cambridge: Perseus.

Virilio, P. (2000). The information bomb. London: Verso.

\section{About the Author}

Wolfgang Hofkirchner

Wolfgang Hofkirchner is Associate Professor at the Vienna University of Technology. Between 2004-2010 he has been University Professor at the Paris-Lodron University of Salzburg. He conducts research in the field of science, technology, and society. In particular, he is interested in the science of information and philosophy of complexity. He has published more than 150 articles and books. He is a founding member of the Unified Theory of Information Research Group and Triple-C. 